\title{
PENILAIAN KERENTANAN DAN KESIAPSIAGAAN BENCANA TSUNAMI DI PESISIR SADENG, GUNUNGKIDUL
}

\author{
Fitria Nucifera1, Widiyana Riasasii', Sutanto Trijuni Putro' ${ }^{2}$, Muh Aris Marfai ${ }^{3}$ \\ 1Program Studi Geografi Fakultas Sains dan Teknologi Universitas AMIKOM Yogyakarta \\ J1. Ringroad Utara, Condongcatur, Sleman, Yogyakarta \\ 2 Jurusan Pendidikan Geografi Fakultas Ilmu Sosial Universitas Negeri Yogyakarta \\ Jl. Colombo No.1, Yogyakarta \\ ${ }^{3}$ Departemen Geografi Lingkungan Fakultas Geografi Universitas Gadjah Mada \\ Sekip Utara, Bulaksumur, Yogyakarta \\ e-mail: fnucifera@amikom.ac.id \\ Diterima: 3 Desember 2018; Direvisi: 14 Juni 2019; Disetujui: 13 Juli 2019
}

\begin{abstract}
Abstrak
Kejadian tsunami di Indonesia mencapai 5\% dari total kejadian tsunami secara global. Pesisir selatan Jawa menjadi salah satu kawasan yang berpotensi tsunami karena letaknya berada pada zona subduksi. Pelabuhan perikanan pesisir Sadeng terletak di pantai pesisir Selatan Yogyakarta dengan potensi terdampak bencana tsunami. Penilaian kerentanan fisik dan sosial di pesisir Sadeng serta kesiapsiagaan masyarakat terhadap bencana tsunami menjadi tujuan dari penelitian. Metode penilaian kerentanan dan kesiapsiagaan menggunakan parameter fisik dengan indikator infrastruktur dan parameter sosial dengan indikator masyarakat. Kawasan pesisir Sadeng tergolong memiliki tingkat kerentanan yang tinggi dikarenakan posisi infrastruktur yang sangat dekat dengan garis pantai (<50 meter) dan kondisi penduduk yang padat menjadikan kawasan ini rentan mengalami kerusakan dan kerugian ketika bencana tsunami terjadi. Dari segi kesiapsiagaan, kawasan ini telah memiliki kesiapsiagaan yang tinggi dalam menghadapi tsunami. Beberapa hal tentang kesiapsiagaan yang masih perlu untuk ditingkatkan lagi adalah tentang jalur evakuasi dan organisasi kebencanaan.
\end{abstract}

Kata kunci: tsunami, kerentanan, kesiapsiagaan, pesisir, Sadeng

\begin{abstract}
Tsunami occurance in Indonesia was 5\% from total global tsunami worldwide. Java Southern Coast prones to tsunami because it is located in subduction zone. This made Sadeng Fishing Port, prones to tsunami because it is located in the Southern Coast of Yogjakarta. Physical and social vulnerability assessment along with community preparedness towards tsunami was the aim of this research. The vulnerability and preparedness assessment method utilized physical parameters with its infrastructure indicator and social parameter with its society indicatior. Sadeng Coastal Area categorized as high vulnerable area prone to tsuami because of their infrastructures built very close to the coastal line ( $<50$ meters), also with dense population develop this area prone to devastation and loss due to tsunami. From the preparedness point of view, this area has a high level of preparedness in facing tsunami. Several points need to be elevated are evacuation routes and rganization of disaster management.
\end{abstract}

Key words: tsunami, vulnerability, preparedness, coastal, Sadeng 


\section{PENDAHULUAN}

Tsunami merupakan bencana alam dengan frekuensi kejadian yang tergolong rendah namun memiliki tingkat daya rusak yang sangat tinggi. Faktor pemicu tsunami antara lain disebabkan oleh gempabumi dasar laut, longsoran bawah laut, longsoran di darat yang jatuh ke laut, proses vulkanisme, jatuhan asteroid dan pergerakan front yang kuat di atmosfer (Grezio et al., 2017) . Sebanyak $80 \%$ kejadian tsunami global dipicu oleh adanya gempa dasar laut (Papadopoulos et al., 2014).

Sebagian besar kejadian tsunami yang dipicu gempabumi terjadi pada zona subduksi sepanjang Ring of Fire di Samudra Pasifik, Samudra Hindia, bagian Timur Laut Samudra Atlantik, Laut Mediterania, Bagian Timur Indonesia dan Filipina serta Laut Karibia (Papadopoulos et al., 2014) Sebanyak $5 \%$ kejadian tsunami global terjadi di Indonesia (UNESCO \& NOAA, 2018). Beberapa kejadian tsunami besar yang pernah terjadi di beberapa lokasi di
Indonesia antara lain pesisir Aceh, Jawa, Flores, Mentawai, Halmahera, Sulawesi, Papua dan Timor (Latief, Puspito, \& Fumihiko, 2000).

Pesisir selatan Jawa merupakan salah satu kawasan yang berpotensi tsunami karena berada pada zona subduksi. Kejadian gempa di selatan Jawa sejak tahun 1900-2015 disajikan dalam Gambar 1. Pada peta tersebut terdapat zona yang cenderung jarang mengalami gempa yang disebut dengan seismic gap. Energi gerakan lempeng tektonik pada zona subduksi terakumulasi pada zona seismic gap dan berpotensi untuk menghasilkan gempa besar yang dapat mengakibatkan tsunami (Sunarto, Marfai, \& Mardiatno, 2010; Sutikno, 2009). Berdasarkan data kejadian tsunami di Indonesia hingga tahun 2000, tercatat telah terjadi tsunami di Pulau Jawa sebanyak 10 kejadian, dengan total korban jiwa mencapai 3.261, atau sebanyak 6\% dari total korban jiwa di Indonesia akibat tsunami (Latief et al., 2000).

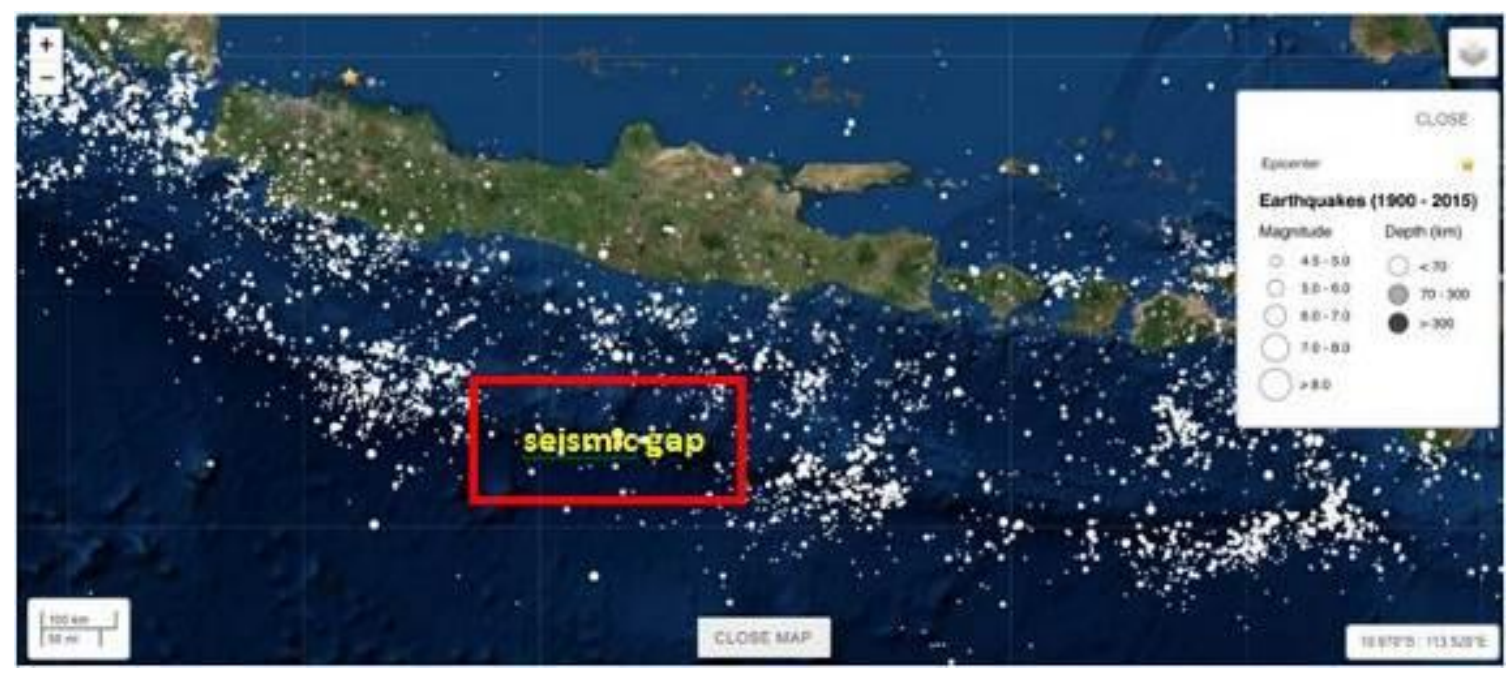

Gambar 1. Kejadian gempa di pesisir selatan Jawa taun 1900 - 2015 (USGS, 2018)

Berdasarkan Hyogo Framework for Action, pengurangan risiko bencana dapat dikategorikan menjadi tiga tahapan: 1) mengurangi atau membatasi ancaman terhadap bahaya; 2) mengurangi kerentanan berkaitan dengan bahaya; dan 3) meningkatkan kesiapsiagaan untuk mengantisipasi, menanggapi dan memulihkan diri dari ancaman bahaya sebuah bencana (United Nations, 2005). Kerentanan diartikan sebagai kondisi kerawanan masyarakat (komunitas) terhadap dampak bahaya bencana, dimana secara umum parameter yang ditentukan adalah fisik, sosial, ekonomi, dan lingkungan. Kerentanan antar komunitas 
akan berbeda, tergantung dengan kondisi masing-masing komunitas (United Nations Office for Disaster Risk Reduction (UNISDR), 2009). Parameter kerentanan dan kesiapsiagaan merupakan parameter yang paling memungkinkan untuk dimodifikasi terkait pengurangan risiko bencana.

Salah satu komunitas yang terpengaruh oleh tsunami adalah masyarakat yang tinggal dan beraktivitas di pesisir terdampak tsunami ketika tsunami terjadi. Salah satu pusat aktifitas di pesisir adalah pelabuhan, baik pelabuhan transportasi maupun pelabuhan ikan. Pelabuhan selalu terdampak oleh adanya tsunami (Dengler \& Uslu, 2011; Wood \& Good, 2004; Wood, Good, \& Goodwin, 2002). Pada umumnya pelabuhan dibangun pada muka air laut atau dekat dengan muka laut dengan material lepas-lepas (unconsolidated), sehingga rentan akan gempa, tsunami, dan likuifaksi (Wood et al., 2002)

Pelabuhan Sadeng merupakan Kawasan Minapolitan yang masuk kedalam wilayah Kabupaten Gunungkidul. Pelabuhan ini masuk ke dalam kawasan Pelabuhan Perikanan Pantai. Di dalam kawasan ini, terdapat berbagai infrastruktur yang menunjang kegiatan pelabuhan perikanan seperti pabrik es, kawasan dermaga, breakwater, kawasan penginapan untuk nelayan luar wilayah, pasar ikan, serta infrastruktur yang mendukung keamanan wilayah seperti kantor TNI AL.

Kegiatan utama di Pelabuhan Sadeng adalah keluar-masuk kapal penangkap ikan, perdagangan ikan, pemancingan dan wisata dengan jumlah yang terbatas. Pada umumnya Pelabuhan Sadeng ramai di siang hari dimana terjadi hilir mudik kapal nelayan dan perdagangan ikan. Aktivitas perkantoran juga aktif di siang hari.

Sebagian besar penghuni sekitar Pelabuhan Sadeng merupakan pendatang dari luar daerah Gunungkidul yang berprofesi sebagai nelayan maupun pedagang ikan.

Secara fisik, Pelabuhan Sadeng berada di suatu teluk dan terhimpit oleh tebing yang tinggi dan terjal di kedua sisinya. Posisi Pelabuhan Sadeng berada di ujung teluk yang merupakan kelurusan dari lembah Bengawan Solo Purba. Secara tipologi pesisir Sadeng tergolong dalam pesisir buatan manusia (Marfai, Cahyadi, \& Anggraini, 2013).

Berdasarkan kondisi topografi lembah yang memanjang dan sosioekonomi, kawasan ini rawan akan ancaman tsunami (Cahyadi, Afianita, Gamayanti, \& Fauziyah, 2012). Perlu dilakukan kajian yang mendukung upaya mitigasi untuk mengurangi risiko bencana. Salah satu cara untuk mengurangi risiko bencana adalah dengan melakukan pengelolaan parameter kerentanan dan kesiapsiagaan.

\section{METODE PENELITIAN}

\section{Penilaian Kerentanan}

Parameter kerentanan tsunami difokuskan pada infrastruktur dan kependudukan, seperti disajikan pada Tabel 1. Penilaian kerentanan tsunami membutuhkan data mengenai kependudukan dan infrastruktur yang mengalami ancaman tsunami (Strunz et al., 2011). Adapun kedua paramater penilaian kerentanan tersebut terbagi menjadi kerentanan fisik dan sosial (Aguirre-Ayerbe et al., 2018).

Kerentanan fisik ditekankan pada kondisi infrastruktur dan penggunaan lahan. Bangunan infrastruktur dinilai berdasarkan fungsi dan nilai ekonomi (González-Riancho et al., 2014). Berdasarkan faktor tersebut, infrastruktur diklasifikasikan menjadi infrastruktur strategis, infrastruktur publik, infrastruktur gawat darurat dan infrastruktur penunjang (listrik, sumberdaya air dan bahan bakar). Analisis penggunaan lahan terkait dengan proses evakuasi dan potensi kerugian ekonomi. 
Tabel 1. Parameter penilaian kerentanan tsunami

\begin{tabular}{lll}
\hline No & Parameter & Indikator \\
\hline 1 & Kerentanan fisik & Jumlah infrastruktur strategis \\
& & Jumlah infrastruktur publik \\
& & Jumlah infrastruktur gawat darurat \\
& & Jumlah infrastruktur listrik, sumberdaya air dan \\
& bahan bakar \\
& & Jenis penggunaan lahan \\
& Kerentanan sosial & Jumlah penduduk \\
& & Kepadatan penduduk \\
\hline Sumber: Modifikasi dari Strunz et al (2011) dan Ayerbe at al (2018)
\end{tabular}

Kondisi kependudukan merupakan bagian dari kerentanan sosial. Analisis kependudukan menggambarkan potensi manusia yang terpapar ancaman bencana tsunami. Jumlah dan kepadatan penduduk berkaitan dengan proses evakuasi ketika terjadi tsunami. Semakin tinggi jumlah dan kepadatan penduduk maka proses evakuasi akan menjadi lebih sulit.

\section{Penilaian Kesiapsiagaan}

Penilaian kesiapsiagaan lebih difokuskan pada perihal terkait institusi. Parameter yang digunakan untuk penilaian kesiapsiagaan dimodifikasi dari AguirreAyerbe et al. (2018) dan Strunz et al. (2011) dimana terdiri dari kesiapsiagaan dan pencegahan. Parameter penilaian kesiapsiagaan tsunami disajikan pada Tabel 2. Adapun menurut UNESCO (2015), kesiapsiagaan dinilai antara lain dengan identifikasi kekurangan yang ditimbulkan oleh kelemahan institusi, organisasi maupun komunitas dalam melakukan antisipasi, respon dan pemulihan bencana tsunami.

Kunci penilaian kesiapsiagaan komunitas antara lain pengetahuan dan kesadaran mengenai risiko tsunami, ketersediaan peta dan informasi bahaya tsunami, ketersediaan sarana jalur evakuasi, keberadaan EWS (early warning system), keberadaan organisasi masyarakat terkait bencana, ketersediaan SOP ketika bencana datang serta keberadaan kegiatan sosialisasi dan simulasi tsunami. Adapun parameter pencegahan tsunami yaitu keberadaan bangunan atau struktur pemecah gelombang.

Tabel 2. Parameter penilaian kesiapsiagaan

\begin{tabular}{lll}
\hline No & Parameter & Indikator \\
\hline 1 & Kesiapsiagaan & Ketersediaan peta dan informasi tsunami \\
& & Ketersediaan jalur evakuasi dan sarananya \\
& & Keberadaan EWS (Early Warning System) \\
& & Keberadaan organisasi masyarakat terkait bencana \\
& & Mekanisme respon ketika terjadi tsunami (SOP) \\
& & Adanya kegiatan sosiasilasi tsunami \\
2 & Pencegahan & Keberadaan bangunan atau struktur pemecah gelombang \\
\hline
\end{tabular}

Sumber: Modifikasi dari Aguirre-Ayerbe et al. (2018) dan Strunz et al. (2011)

\section{HASIL DAN PEMBAHASAN \\ Kerentanan Tsunami}

Penilaian kerentanan didasarkan pada kondisi infrastruktur dan kependudukan. Penilaian infratsruktur ini secara tidak langsung berhubungan dengan aset baik itu berupa aset pemerintah maupun aset masyarakat. Adapun infrastruktur yang diidentifikasi adalah infrastruktur strategis, infrastruktur publik, infrastruktur gawat darurat dan infrastruktur listrik, sumberdaya air dan bahan bakar. Jenis infrastruktur yang teridentifikasi di pesisir Sadeng disajikan pada Tabel 3. 
Tabel 3. Jenis infrastruktur di pesisir Sadeng

\begin{tabular}{lll}
\hline No & \multicolumn{1}{c}{ Jenis Infrastruktur } & \multicolumn{1}{c}{ Nama Infrastruktur } \\
\hline 1 & Infrastruktur strategis & Pelabuhan perikanan pantai \\
& & Tempat pelelangan ikan \\
& & Unit EWS dan stasiun pasang surut \\
& & Kantor Pelabuhan Perikanan \\
3 & Infrastruktur publik & 2 Unit Bangunan Masjid \\
& Infrastruktur gawat darurat & POS SAR Satlinmas DIY \\
& & Kantor Pos Pengawasan Keselamatan \\
& & Pelayaran (Poswaskespel) \\
4 & Infrastruktur listrik, sumberdaya air & Kantor Direktorat Polisi Air (DIT POLAIR) \\
& dan bahan bakar & SPBU Sadeng \\
& & Sumur bor \\
& & Gardu listrik \\
\hline
\end{tabular}

Sumber: Hasil penelitian, 2018

Pesisir Sadeng merupakan kawasan strategis karena merupakan pelabuhan perikanan pantai. Oleh karena itu maka seluruh infrastruktur yang menunjang fungsi sebagai pelabuhan perikanan termasuk dalam infrastruktur strategis. Keberadaan pelabuhan perikanan Sadeng mendukung suplai ikan laut untuk wilayah DIY hingga Cilacap, Jakarta dan Surabaya (Rakhmanda, Suadi., \& Supardi Djasmani, 2019). Fungsi pelabuhan perikanan Sadeng sebagai kawasan strategis akan mempengaruhi kondisi daerah lain khususnya dalam hal produksi dan distribusi ikan laut. Kejadian bencana tsunami berpotensi mengganggu fungsi pelabuhan perikanan yang secara langsung mempengaruhi suplai ikan di daerah pemasaran.

Infrastruktur penunjang fungsi pelabuhan perikanan pantai di pesisir Sadeng antara lain: kantor pelabuhan perikanan, tempat pelelangan ikan, SPBU, pabrik es dan stasiun pasang surut. Posisi infrastruktur ini sangat dekat dengan garis pantai dermaga (< 50 meter) sehingga potensi kerugian dan kerusakan akibat tsunami cukup tinggi. Kondisi tersebut menjadikan kawasan ini memiliki kerentanan yang tinggi terhadap ancaman tsunami. Gambar 2 menunjukkan situasi infrastruktur penunjang pelabuhan perikanan Sadeng.

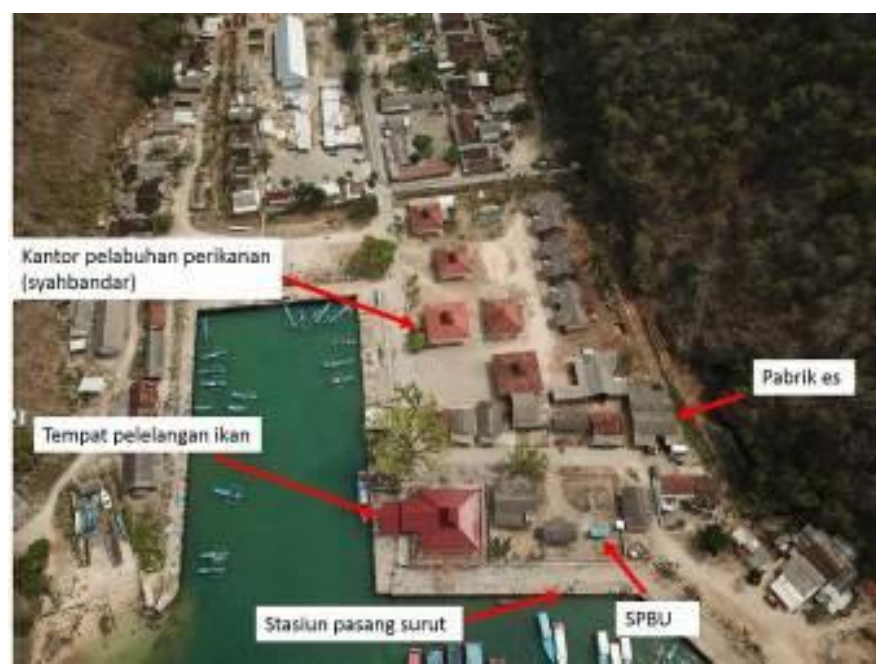

Gambar 2. Pelabuhan Perikanan Sadeng

(Sumber: Dokumentasi Penelitian, 2018)

Infrastruktur publik yang terdapat di pelabuhan Sadeng hanya masjid, dimana insfrastruktur publik merupakan infrastruktur yang dapat dimanfaatkan oleh masyarakat luas. Infrastruktur gawat darurat, yang berfungsi jika berada dalam 
kondisi darurat, dapat ditemukan di sana, yang berupa POS SAR, Kantor Poswakespel dan DIT POLAIR.

Selain itu, keberadaan infrastruktur listrik, sumberdaya air dan bahan bakar juga tidak kalah penting. Hal ini berkaitan dengan masa tanggap darurat bencana. Apabila infrastruktur tersebut rusak pada saat bencana maka masyarakat akan mengalami kesulitan.
Secara spasial, penggunaan lahan di kawasan pesisir Sadeng, khususnya di sekitar pelabuhan perikanan, terdiri dari perkantoran (pelabuhan ikan), perdagangan (warung makan ikan), pemukiman, dan lahan kosong. Kondisi penggunaan lahan di kawasan pesisir Sadeng secara spasial disajikan melalui peta pada Gambar 3.

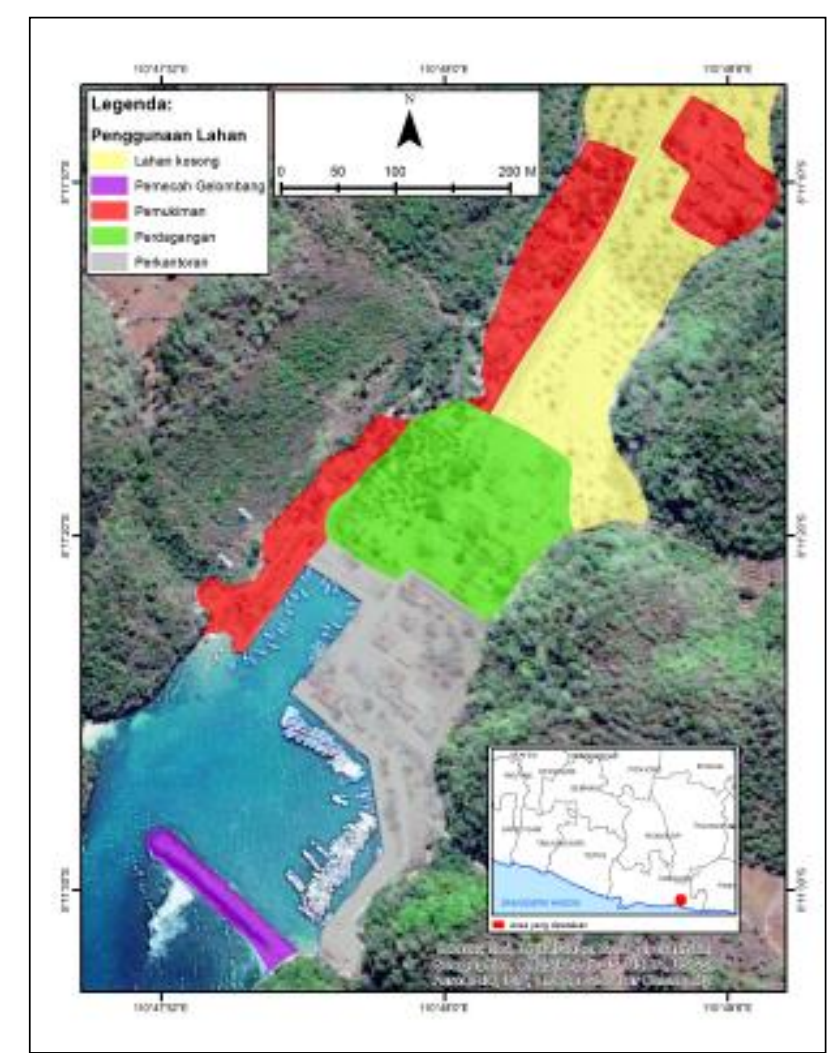

Gambar 3. Peta Penggunaan Lahan Pesisir Sadeng (Sumber: Hasil Penelitian, 2018)

Kondisi kependudukan memiliki peranan penting dalam penanggulangan bencana. Pesisir Sadeng dihuni oleh sebagian besar kelompok nelayan. Penduduk tetap yang tinggal di kawasan ini berjumlah 300 jiwa. Sebagian penduduk di kawasan ini bersifat nomaden atau tidak menetap. Mereka merupakan nelayan yang berasal dari berbagai daerah seperti Banyuwangi, Cilacap, Surabaya hingga Sulawesi. Jumlah penduduk pada saat musim ikan akan meningkat.

Permukiman nelayan terpusat di bagian barat dan sebagian kecil di bagian timur. Luas permukiman di kawasan ini
28,1 hektar dengan kepadatan penduduk 11 jiwa per hektar. Kondisi kepadatan penduduk yang tergolong padat berpengaruh pada proses evakuasi saat terjadi bencana tsunami. Proses evakuasi sebaiknya dilaksanakan secara sistematis dan komunal sehingga lebih efektif.

Kawasan pesisir Sadeng tergolong memiliki tingkat kerentanan yang tinggi dari segi infrastruktur dan kependudukan. Posisi infrastruktur yang sangat dekat dengan garis pantai dan kondisi penduduk yang padat menjadikan kawasan ini rentan mengalami kerusakan dan kerugian ketika bencana tsunami terjadi. 


\section{Kesiapsiagaan Tsunami}

Kesiapsiagaan masyarakat dalam menghadapi bencana secara garis besar meliputi pengorganisasian komunitas, keberadaan sarana prasarana jalur evakuasi dan EWS, serta tingkat pengetahuan masyarakat tentang tsunami. Informasi mengenai kesiapsiagaan bencana diperoleh dari wawancara terhadap masyarakat setempat.

Tingkat pengetahuan dan kesadaran masyarakat terhadap bencana tsunami di pesisir Sadeng cukup tinggi. Sebagian besar masyarakat pesisir Sadeng sudah memahami tanda-tanda kejadian tsunami berupa air laut yang surut secara tiba-tiba. Ketika mengalami tanda-tanda tersebut, masyarakat merespon dengan bersiap-siap untuk mengevakuasi diri sendiri beserta keluarga. Bentuk respon berupa mengemasi dokumen dan barang berharga, mempersiapkan kendaraan dan menuju titik kumpul.

Keberadaan organisasi masyarakat dalam pengelolaan bencana secara formal belum terbentuk. Kelompok nelayan merupakan satu-satunya organisasi masyarakat yang eksis di kawasan pesisir Sadeng. Peran organisasi kebencanaan dalam siklus manajemen bencana sangat penting bagi masyarakat dan pemerintah. Pengembangan dan penguatan kapasitas kelembagaan bagi pemerintah dan masyarakat merupakan salah satu tujuan strategis penanggulangan bencana yang tercantum dalam Hyogo Framework For Action.

Walaupun belum terbentuk organisasi masyarakat mengenai kebencanaan secara formal, masyarakat sudah memiliki alur respon bencana secara informal. Tim SAR DIY Pos Sadeng berperan penting dalam mekanisme respon terhadap kejadian bencana. Ketika terjadi tanda-tanda tsunami, masyarakat mengevakuasi diri sendiri dan keluarganya dengan dipandu Tim SAR DIY.

Sosialisasi dan simulasi bencana tsunami merupakan salah satu upaya dalam meningkatkan kesiapsiagaan masyarakat. BPBD Kabupaten Gunungkidul bersama Polda DIY secara rutin mengadakan simulasi gempabumi dan tsunami di kawasan pesisir Sadeng. Respon penanggulangan bencana tsunami secara sistematis digelar dalam simulasi tersebut.

Peta dan informasi mengenai bahaya tsunami dan jalur evakuasi telah terpasang di tempat yang strategis (Gambar 4). Keberadaan peta dan informasi tersebut dapat dilihat dengan mudah oleh masyarakat dan para wisatawan yang mengunjungi Pantai Sadeng. Peta tersebut cukup informatif dalam mendeksripsikan jalur evakuasi bencana tsunami.

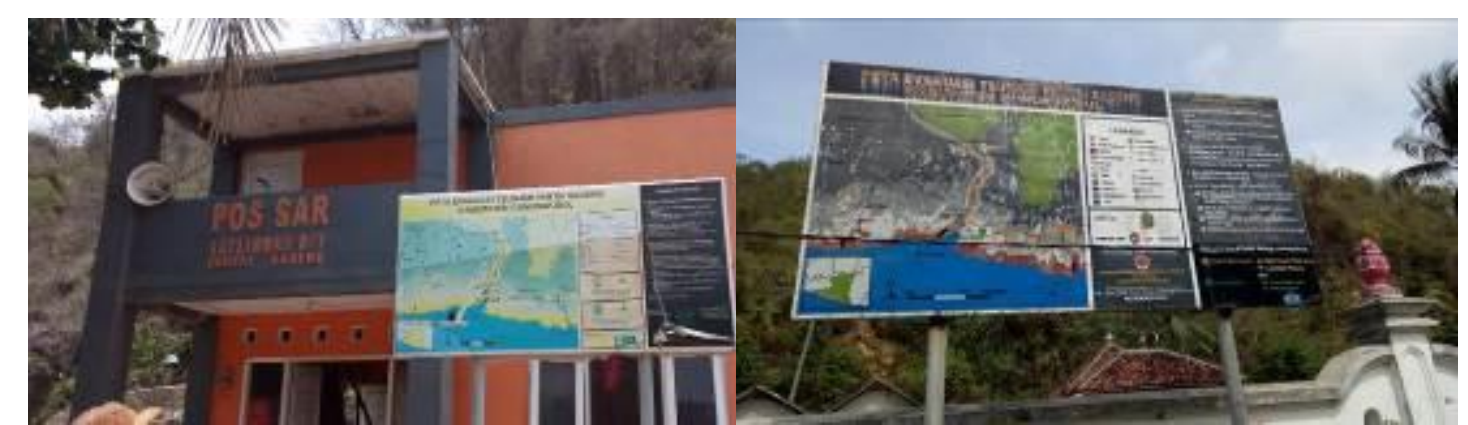

Gambar 4. Peta dan informasi jalur evakuasi tsunami yang dipasang di dekat dermaga (kiri) dan di pintu masuk kawasan pelabuhan (kanan) (Sumber: Dokumentasi Penelitian, 2018)

Papan penunjuk arah jalur evakuasi terpasang di beberapa lokasi yang strategis dan dapat dengan mudah dilihat Gambar 5. Secara umum terdapat dua jalur evakuasi di kawasan pesisir Sadeng (Gambar 6).
Jalur evakuasi yang pertama mengarah ke bukit yang berada pada bagian depan Teluk Sadeng. Jalur evakuasi ini direkomendasi bagi masyarakat yang pada saat kejadian tsunami berada di bagian timur dermaga. 
Kondisi jalan pada jalur evakuasi ini kurang baik dikarenakan masih berupa jalan rabat beton (Gambar 7). Jalur evakuasi yang kedua mengarah ke utara menjauhi dermaga menuju titik kumpul di lapangan Pucung. Jalur ini direkomendasikan bagi masyarakat yang pada saat kejadian tsunami berada di bagian utara dermaga.
Kekurangan dari jalur evakuasi ini adalah jarak dengan titik kumpul yang cukup jauh. Kondisi kedua jalur evakuasi ini perlu dievaluasi lebih lanjut untuk mendapatkan rute jalur evakuasi yang paling efektif dan efisien sehingga masyarakat dapat mengevakuasi diri dengan cepat.

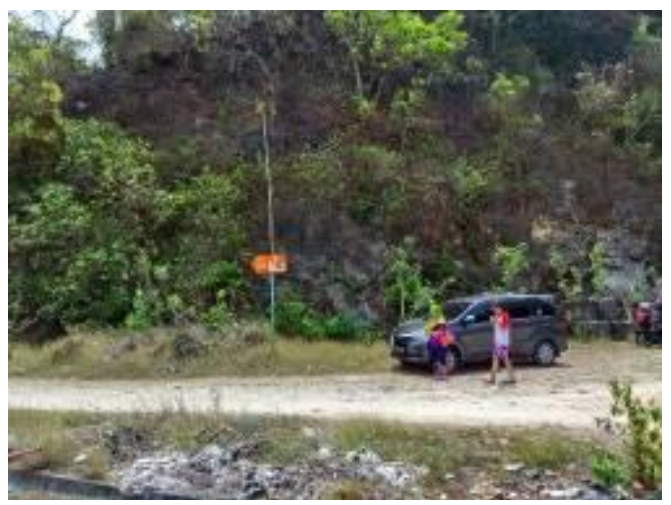

Gambar 5. Papan penunjuk arah jalur evakuasi di Pantai Sadeng

(Sumber: Dokumentasi Penelitian, 2018)
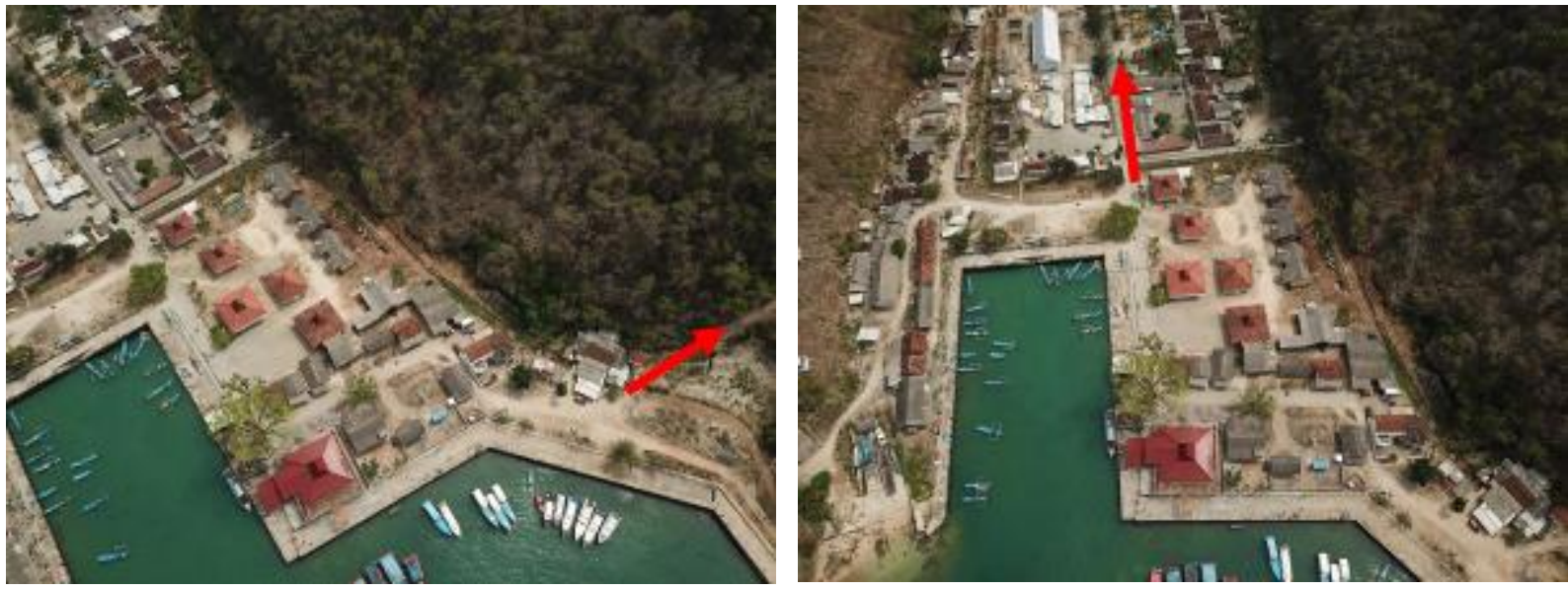

Gambar 6. Jalur evakuasi pertama mengarah ke bukit (kiri) dan jalur evakuasi kedua mengarah ke utara (kanan) (Sumber: Dokumentasi Penelitian, 2018)

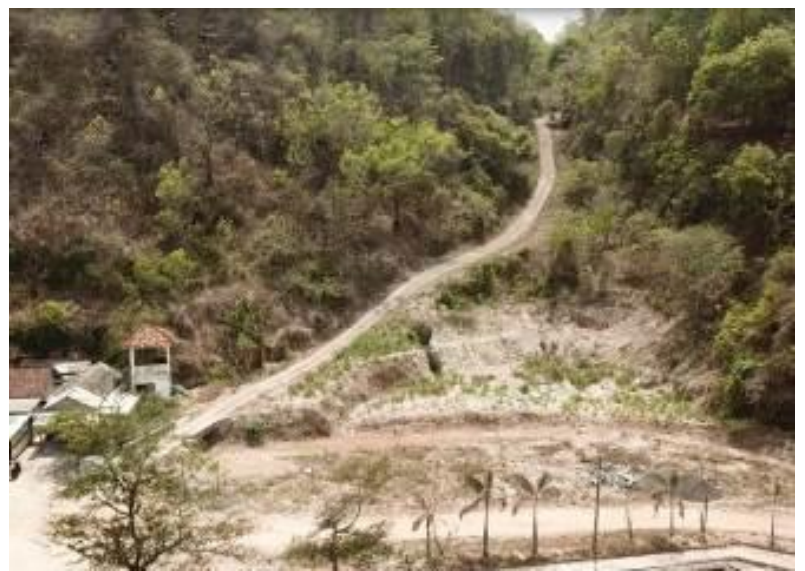

Gambar 7. Kondisi jalan pada jalur evakuasi (Sumber: Dokumentasi Penelitian, 2018) 
Kawasan pesisir Sadeng dilengkapi dengan stasiun pasang surut yang merupakan jaringan dari InaTEWS (Indonesia Tsunami Early Warning System) sebagai sistem peringatan dini tsunami
(Gambar 8). Peringatan dini tsunami akan disebarkan melalui sirine yang berada di sebelah barat dekat dengan bukit. Masyarakat sudah memahami tanda peringatan dini tersebut.

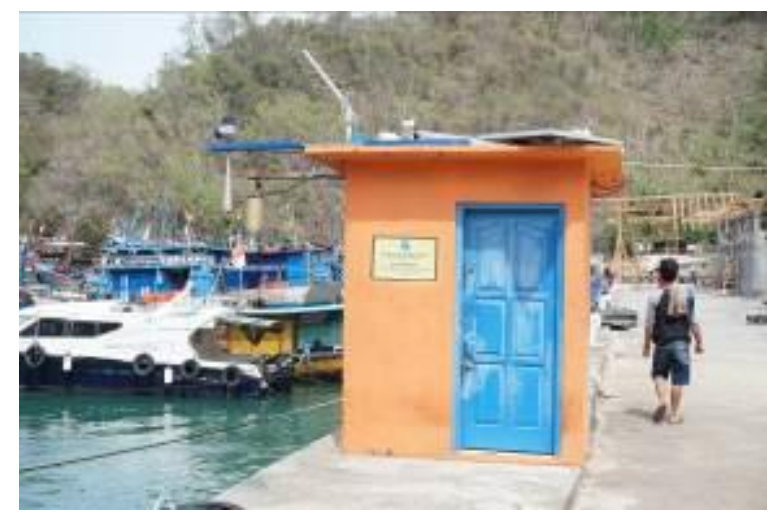

Gambar 8. Stasiun pasang surut dan peringatan dini (Sumber: Dokumentasi Penelitian, 2018)

Seperti pada umumnya kawasan pelabuhan, kawasan pelabuhan Sadeng juga dilengkapi dengan bangunan pemecah gelombang. Bangunan pemecah gelombang ini memiliki fungsi proteksi terhadap tsunami. Akan tetapi bangunan pemecah ini tidak diperuntukkan secara khusus untuk melindungi pantai dari tsunami.

Kawasan pesisir Sadeng telah memiliki kesiapsiagaan yang tinggi dalam menghadapi tsunami. Beberapa hal tentang kesiapsiagaan yang masih perlu untuk ditingkatkan lagi adalah tentang jalur evakuasi dan organisasi kebencanaan.

\section{KESIMPULAN}

Kawasan Pesisir Sadeng yang terdiri atas kawasan pelabuhan dan permukiman, memiliki tingkat kerentanan bahaya yang tinggi terhadap bencana tsunami. Walaupun demikian, lokasi kajian memiliki tingkat kesapsiagaan yang tinggi dalam menghadapi bencana tersebut. Parameter yang harus ditingkatkan tekait kesiapsiagaan menghadapi bencana terkait dengan pengorganisasian penanggulangan bencana termasuk didalamnya penyiapan prosedur tertulis sebagai acuan yang akan diimplementasikan ketika bencana terjadi.

\section{UCAPAN TERIMA KASIH}

Penelitian ini merupakan bagian dari Hibah Penelitian Internal Universitas AMIKOM Yogyakarta yang didanai oleh Direktorat Penelitian Universitas AMIKOM Yogyakarta. Penulis mengucapkan terimakasih atas pendanaan yang diberikan dalam penelitian ini.

\section{DAFTAR PUSTAKA}

Aguirre-Ayerbe, I., Martínez Sánchez, J., Aniel-Quiroga, I., González-Riancho, P., Al-Yahyai, S., González, M., \& Medina, R. (2018). From tsunami risk assessment to disaster risk reduction The case of Oman. Natural Hazards and Earth System Sciences, 18(8). https://doi.org/10.5194/nhess-182241-2018

Cahyadi, A., Afianita, I., Gamayanti, P., \& Fauziyah, S. (2012). EVALUASI TATA RUANG PESISIR SADENG GUNUNGKIDUL (Perspektif Pengurangan Risiko Bencana). Prosiding Seminar Nasional SCAN (Sustainable, Culture, Architecture and Nature) Ke 3 Jurusan Teknik Universitas Atma Jaya Yogyakarta. Yogyakarta: Universitas Atma Jaya Yogyakarta. 
Dengler, L., \& Uslu, B. (2011). Effects of harbor modification on crescent city, California's Tsunami vulnerability. Pure and Applied Geophysics, 168(6-7). https://doi.org/10.1007/s00024-0100224-8

González-Riancho, P., Aguirre-Ayerbe, I., García-Aguilar, O., Medina, R., González, M., Aniel-Quiroga, I., ... Gavidia, F. (2014). Integrated tsunami vulnerability and risk assessment: Application to the coastal area of $\mathrm{El}$ Salvador. Natural Hazards and Earth System Sciences, 14(5). https://doi.org/10.5194/nhess-141223-2014

Grezio, A., Babeyko, A., Baptista, M. A., Behrens, J., Costa, A., Davies, G., ... Thio, H. K. (2017). Probabilistic Tsunami Hazard Analysis: Multiple Sources and Global Applications. Reviews of Geophysics, 55(4). https://doi.org/10.1002/2017RG00057 9

Latief, H., Puspito, N. T., \& Fumihiko, I. (2000). Tsunami Catalog and Zones in Indonesia. Journal of Natural Disaster Science, Vol. 22.

Marfai, M. A., Cahyadi, A., \& Anggraini, D. F. (2013). Tipologi, Dinamika, dan Potensi Bencana Di Pesisir Kawasan Karst Kabupaten Gunungkidul. Forum Geografi, 27(2).

Papadopoulos, G. A., Gràcia, E., Urgeles, R., Sallares, V., de Martini, P. M., Pantosti, D., Papageorgiou, A. (2014). Historical and pre-historical tsunamis in the Mediterranean and its connected seas: Geological signatures, generation mechanisms and coastal impacts. Marine Geology, 354. https://doi.org/10.1016/j.margeo.201 4.04 .014

Rakhmanda, A., Suadi., \& Supardi Djasmani, S. (2019). Role of Fisher Group in The Fisheries Development in Sadeng Coast Gunungkidul
Regency. Sodality: Jurnal Sosiologi Pedesaan, 6(2). https://doi.org/10.22500/ sodality.v6i 2.23225

Strunz, G., Post, J., Zosseder, K., Wegscheider, S., Mück, M., Riedlinger, T., Muhari, A. (2011). Tsunami risk assessment in Indonesia. Natural Hazards and Earth System Science, 11(1). https://doi.org/10.5194/nhess-11-672011

Sunarto, Marfai, M. A., \& Mardiatno, D. (2010). Multirisk assessment of Parangtritis Coastal Area (p. 210). Yogyakarta: Gadjah Mada University Press.

Sutikno. (2009). Indonesia Negeri 1001 Bencana. Yogyakarta: Makalah dalam Seminas Sistem Informasi Kebencanaan Sebagai Sebuah Kearifan di Negeri 1001 Bencana, 3 - 5 Desember 2009. Yogyakarta.

UNESCO. (2015). TSUNAMI RISK ASSESSMENT AND MITIGATION FOR THE INDIAN OCEAN; knowing your tsunami risk - and what to do about it. IOC Manuals and Guides No. 52, Second Edi(July).

UNESCO, \& NOAA. (2018). Tsunami Sources 1610 B.C. to A.D. 2017. International Tsunami Information Center. Cited in www.tsunamiwave.org

United Nations. (2005). Hyogo Framework for Action 2005-2015. World Conference on Disaster Reduction, (January). https://doi.org/10.1017/CBO9781107 415324.004

United Nations Office for Disaster Risk Reduction (UNISDR). (2009). 2009 UNISDR Terminology on Disaster Risk Reduction. International Stratergy for Disaster Reduction (ISDR). https://doi.org/978-600-6937-11-3 
USGS. (2018). Earthquake Catalog. Cited in https://earthquake.usgs.gov/earthqu akes/search/ [2 November 2018]

Wood, N. J., \& Good, J. W. (2004). Vulnerability of port and harbor communities to earthquake and tsunami hazards: The use of GIS in community hazard planning. Coastal Management, 32(3). https://doi.org/10.1080/089207504904 48622

Wood, N. J., Good, J. W., \& Goodwin, R. F. (2002). Vulnerability Assessment of a Port and Harbor Community to Earthquake and Tsunami Hazards: Integrating Technical Expert and Stakeholder Input. Natural Hazards Review, $3(4)$. https://doi.org/10.1061/(asce)15276988(2002)3:4(148) 